\title{
Development of a liquid phase radioimmunoassay for the measurement of serum ferritin levels for the detection of Covid-19 in patients
}

\author{
Emil Michael Riad' ${ }^{1}$ - Manal Asem Emam² $\cdot$ Nahed Hassan Ebeid ${ }^{1} \cdot$ Ahmed Sami El-bayoumy $^{1}$. \\ Khaled Mohamed Sallam ${ }^{1} \cdot$ Nagy Lahzy Mehany ${ }^{1} \cdot$ Shadia Abdel-Hamid Fathy $^{2}$
}

Received: 6 November 2021 / Accepted: 15 January 2022 / Published online: 5 February 2022

(c) The Author(s) 2022

\begin{abstract}
The aim of this study was the development and analytically validation of a radioimmunoassay system for the measurement of the serum ferritin concentration as one of the laboratory biomarkers for infection by Covid-19. The main components of the system were prepared in our laboratories. The first component ferritin was extracted and purified from human spleen with high purity. The second component was the 125I-labelled ferritin tracer, prepared using Chloramine-T method. Furthermore anti-ferritin antibodies and ferritin standards were provided. The developed system is sensitive, precise, reproducible and. can be translated into a kit formulation suitable for measuring serum ferritin for the detection of Covid-19 in patients at low costs and high efficiency.
\end{abstract}

Keywords Ferritin $\cdot$ Covid-19 $\cdot$ Radioimmunoassay $\cdot$ Labelling $\cdot I^{125} \cdot$ Tracer

\section{Introduction}

COVID-19 (Coronavirus disease-2019) is an emerging infectious disease that has been stated as a worldwide public health emergency by the World Health Organization (WHO). Since the start of the pandemic in Wuhan, China, over 177 million cumulative cases and about 3.9 million deaths globally worldwide was recorded [1]. COVID-19 has a mild influenza-like infection or may be asymptomatic, a small percentage of patients progress acute respiratory distress syndrome (ARDS), severe pneumonia, multi-organ failure, and can even die [2].

Patients with COVID-19 show hyperinflammation and concomitant biomarkers which consist of elevated serum ferritin, C-reactive protein (CRP), procalcitonin (PCT), D-dimer and this may be helpful for risk stratification. [3-6]

Emil Michael Riad

Emil_mishail@yahoo.com

1 Department of Labeled Compounds, Hot labs Centre, Atomic Energy Authority, Cairo, Egypt

2 Department of Biochemistry, Faculty of Science, Ain Shams University, Cairo, Egypt
The amount of iron stored in the body correlates with serum ferritin levels in both healthy and sick people. Unlike serum iron, serum ferritin concentration does not fluctuate from day to day. Because of its relatively high stability and solubility, as well as its direct proportionality to body iron stores in normal persons, serum ferritin is the most commonly used indicator of total body iron storage [7, 8].

Serum ferritin is one of many blood tests used to accurately diagnose and treat a wide range of diseases, and it is likely the most effective marker in most populations [9].

Radioimmunoassay technique for serum ferritin detection depends on several components which was locally prepared to decrease the cost and increase availability of the kit; starting with extraction and purification of ferritin from human spleen to use it as an antigen used for preparation of ${ }^{125}$ I-Ferritin tracer, induce production of ferritin antibodies with high specificity and affinity for ferritin antigen and also to prepare wide range of ferritin standards. This report use double antibody liquid phase technique to prepare the system and separate bound from free ferritin antigen [10, 11].

The aim of this study was to develop ferritin radioimmunoassay system to facilitate detection of serum ferritin level using locally prepared components which will provide a low cost, long term uniform batches, efficient specifications for medical diagnostic purposes, as well as avoiding 
problems resulted from irregular supply and deterioration of the sensitive biodegradable materials during transportation from the original manufacturing countries. The prepared kit serves to cover the increased demand by physicians for ferritin test which is considered a useful laborartory biomarker for infection by Covid-19.

\section{Experimental}

\section{Reagents}

Phosphate buffer 0.5 M, pH 7.4; Phosphate buffer saline (PBS) $0.05 \mathrm{M}, \mathrm{pH} 7.4$; assay buffer: $0.05 \mathrm{M}$ PBS pH7.4 containing $1 \mathrm{mg} / \mathrm{ml}$ bovine serum albumin; Chloramine-T (Ch-T); Sodium metabisulphite (MBS); Normal (inactivated) rabbit serum (NRS); sheep anti-rabbit serum (2nd ab) locally produced; PEG-8000; $\mathrm{Na}^{125} \mathrm{I}(3700 \mathrm{MBq} / \mathrm{ml})$ carrier and reductant free (Institute of Isotopes, Budapest, Hungary). All other chemicals used in this report were provided from Sigma Chemical Co. with high quality and purity.

\section{Ferritin extraction and purification}

Ferritin was extracted from human spleen obtained at autopsy from the Department of Pathology of Zagazig University Hospital, The tissue was frozen and stored at $-10{ }^{\circ} \mathrm{C}$ till used. The extraction and purification steps applied based on the methods of Suryakala et al. [12] Cetinkaya et al. [13] and Page et al. [14] as following:

Homogenation The tissue was cut into small pieces and homogenized for $10 \mathrm{~min}$ at $4{ }^{\circ} \mathrm{C}$ in Waring blender after adding 1.5 fold of distilled water.

Heat denaturation The homogenate was heated rapidly to $70{ }^{\circ} \mathrm{C}$ in a water bath and maintained at $70-75^{\circ} \mathrm{C}$ for $10 \mathrm{~min}$ with continuous stirring, after cooling, the homogenate was centrifuged for $30 \mathrm{~min}$ at $5000 \mathrm{rpm}$ and remove the coagulated protein precipitated. The supernatant was then filtered through whatman filter paper no. 1 using Buchner funnel and suction to remove traces of low density coagulum.

Ammonium sulphate precipitation Crude ferritin was precipitated by half saturated ammonium sulphate added slowly with constant stirring. Adjust $\mathrm{pH}$ at 5.2 while adding ammonium sulphate. The solution was left overnight at $4{ }^{\circ} \mathrm{C}$ then centrifuge at $2000 \mathrm{rpm}$ for $30 \mathrm{~min}$ the supernatant was discarded and the insoluble fraction which contained the ferritin fraction was dissolved in a minimal volume of distilled water. The precipitation procedure, using 50\% ammonium sulphate, was repeated twice more. Finally, the final precipitate was dissolved in the smallest possible volume of distilled water and dialyzed exhaustively overnight at $4{ }^{\circ} \mathrm{C}$ against distilled water.

Gel filtration on Sephacryl S-300 Six ml of the crude ferritin preparation was applied to a $2.6 \times 100 \mathrm{~cm}$ column filled with Sephacryl S-300 equilibrated with Tris-HCl buffer, $0.05 \mathrm{M}, \mathrm{pH} 7.1$; containing $0.1 \mathrm{M} \mathrm{NaCl}$, at a rate of passage of $40 \mathrm{ml} / \mathrm{h}$, which was maintained with the aid of peristaltic pump. The protein in the eluate was recorded from its absorption at $280 \mathrm{~mm}$ with the aid of the UVVisible spectrophotometer. The ferritin fraction was easily identified from its characteristic orange-brown coloration. This step was repeated for the fractions containing ferritin with high concentration for more purification.

After each step the protein and ferritin contents were measured using commercial colorimetric kit (Spinreact) and enzyme immunoassay kit (Monobind) respectively. The purity and recovery percent were calculated mathematically and recorded.

\section{Preparation of ${ }^{125} \mathrm{I}$ - ferritin tracer}

Labelling of ferritin with 125I takes place using Hunter and Greenwood method (1962) [15] with slight modification. To obtain a high radiochemical yield and a good radiochemical purity all parameters such as effect of reaction time, $\mathrm{pH}$, concentration of oxidizing agent (ChloramineT) and concentration of substrate (ferritin) were studied. Labelling process starts by dissolving $10 \mu \mathrm{g}$ ferritin in $10 \mu \mathrm{PBS} 0.05 \mathrm{M}$ pH 7.4 in eppendorf, followed by addition of $50 \mu \mathrm{l}$ of phosphate buffer saline $(0.5 \mathrm{M}, \mathrm{pH} 7.4)$, and $10 \mu \mathrm{l}$ of $\mathrm{Na} 125 \mathrm{I}$ of $1 \mathrm{mCi}(37 \mathrm{MBq})$ activity. The reaction was started by addition of $10 \mu \mathrm{l}$ chloramine-T (2 mg Ch-T dissolved in $1 \mathrm{ml}$ of PBS $0.5 \mathrm{M} \mathrm{pH} \mathrm{7.4)} \mathrm{as}$ oxidizing agent. The reaction mixture was gently vortexed for $30 \mathrm{~s}$. at room temperature and quenched by the addition of $50 \mu \mathrm{l}$ of sodium metabisulphite $(2 \mathrm{mg}$ MBS dissolved in $1 \mathrm{ml}$ dist. Water) followed by addition of $5 \mu \mathrm{l}$ of $0.1 \mathrm{M}$ $\mathrm{KI}$ as a carrier. The labeling yield and specific activity of the produced tracer was calculated after purification using Sephadex G-25 column at flow rate $0.5 \mathrm{ml} / \mathrm{min}$. The radiochemical purity of the tracer was detected using paper electrophoresis.

\section{Optimization of factors affecting the iodination process}

Effect of reaction time: The iodination technique was studied with different reaction time ranged from 20 to $600 \mathrm{~s}$.

Effect of $p H$ : The iodination technique was studied using buffer at different $\mathrm{pH}$ values ranged from 4 to 10 . 
Effect of oxidizing agent (chloramine-T) concentration: The iodination technique was carried out using different concentrations of the oxidizing agent (Ch-T) ranged from 5 to $40 \mu \mathrm{g}$.

Effect of substrate (ferritin) concentration: The iodination process was carried out using different concentrations of the substrate (ferritin) ranged from 2.5 to $20 \mu \mathrm{g}$.

\section{Production of anti-ferritin polyclonal antibodies}

Production of ferritin polyclonal antibody was carried out through immunization of four male mature white New- Zealand rabbits weighing 2-3 kg (R1-R4) with purified ferritin antigen as immunogen according to Barnett et al. [16] and Goldie and Thomas [17]. Five injections were administered, one primary and four booster injections, at four weeks intervals. For primary injection, each rabbit received $400 \mu \mathrm{g}$ of immunogen in $1 \mathrm{ml}$ emulsion prepared by mixing with complete Freund's adjuvant. For booster injections, each rabbit received $200 \mu \mathrm{g}$ of the immunogen in $1 \mathrm{ml}$ emulsion prepared by mixing with incomplete Freund's adjuvant according to Zola H. [18] and Pillai and Bhandarkar [19]. Blood samples were collected 3 weeks after each injection and antibody titre was assessed by measuring the final dilution necessary to bind $50 \%$ of labelled ferritin used in the assay.

\section{Preparation of ferritin standards}

A stock standard of ferritin at a concentration of $10 \mathrm{mg} / 1$ was prepared in assay buffer and suitable portions were frozen at $-20{ }^{\circ} \mathrm{C}$ until needed. On the day of assay a portion was removed and, after thawing, a series of working standards was prepared by dilution in the same buffer to cover the range $0-1000 \mathrm{ng} / \mathrm{ml}[20]$.

\section{Optimization of the liquid-phase RIA system}

The assay range was set at $0-1000 \mathrm{ng} / \mathrm{ml}$. Standard curves were set up and studied at different radio-activities of the tracer, different temperatures $\left(4,25\right.$ and $\left.37^{\circ} \mathrm{C}\right)$ and different incubation time ranged from ( 1 to $24 \mathrm{~h}$ ). The optimal concentrations of the reagents and the assay reaction parameters were chosen to give a standard curve with a desirable slope and minimum imprecision.

\section{Results and discussion}

Ferritin extraction and purification was considered the backbone for the prepared system because it produces the main component which used for preparation of ferritin tracer, ferritin standard and also used to produce the ferritin polyclonal antibodies.

\section{Ferritin extraction and purification from human spleen}

After homogenation and heat denaturation step for $235 \mathrm{gm}$ human spleen the extract undergo centrifugation and the protein content and ferritin content was measured in a sample from the $30 \mathrm{ml}$ supernatant using commercial colorimetric kit (Spinreact) and enzyme immunoassay kit (Monobind) respectively, the results was $1306 \pm 4.19 \mathrm{mg}$ and $24 \pm 0.18 \mathrm{mg}$ respectively. The purity and recovery percent was calculated mathematically to be $1.84 \%$ and $100 \%$ respectively.

After successive precipitation steps using 50\% saturated ammonium sulphate and extensive dialysis the content of protein and ferritin in $25 \mathrm{ml}$ crude extract was measured to be $480 \pm 1.54 \mathrm{mg}$ and $22.3 \pm 0.175 \mathrm{mg}$ respectively with purity and recovery percent to be $4.65 \%$ and $92.9 \%$ respectively

After dialysis, the crude ferritin extract was applied onto $16 \times 90 \mathrm{~cm}$ gel filtration Sephacryl S-300 high resolution column, then eluted isocratically using $0.05 \mathrm{M}$ phosphate buffer $\mathrm{pH} 7.4$ and $5 \mathrm{ml}$ fractions were collected at a flow rate of 0.5 $\mathrm{ml} / \mathrm{min}$. five Peaks was obtained each peak was estimated for ferritin content, the results show that the ferritin was concentrated in the second peak with protein concentration $60.5 \pm 0.475 \mathrm{mg}$ and ferritin concentration $17.6 \pm 0138 \mathrm{mg}$ with purity and recovery percent to be 29.09 and $73.3 \%$ respectively

The second peak was collected and reapplied on the same column for further purification. One sharp peak of highly purified ferritin was obtained $(5 \mathrm{ml})$ and the protein and ferritin content was estimated, the results were $15.3 \pm 0.12$

Table 1 Results of purification steps for human spleen ferritin

\begin{tabular}{lllccrrr}
\hline No & Purification step & $\begin{array}{l}\text { Volume } \\
(\mathrm{ml})\end{array}$ & Total protein $(\mathrm{mg})$ & Total ferritin (m) & $\begin{array}{l}\text { Ferritin / } \\
\text { protein ratio }\end{array}$ & $\begin{array}{l}\text { Purity } \\
\%\end{array}$ & $\begin{array}{l}\text { Recovery } \\
\%\end{array}$ \\
\hline 1 & After heating the extract & 30 & $1306 \pm 4.19$ & $24 \pm 0.18$ & 0.02 & 1.84 & 100 \\
2 & After Amm. Sulphate Precipitate & 25 & $480 \pm 1.54$ & $22.3 \pm 0.175$ & 0.05 & 4.65 & 92.9 \\
3 & After 1st Sephacryl S-300 purification & 10 & $60.5 \pm 0.475$ & $17.6 \pm 0.138$ & 0.29 & 29.09 & 73.3 \\
4 & After 2nd Sephacryl S300 purification & 5 & $15.3 \pm 0.12$ & $15.2 \pm 0.119$ & 0.99 & 99.35 & 63.3 \\
\hline
\end{tabular}


$\mathrm{mg}$ and $15.2 \pm 0.119 \mathrm{mg}$ respectively, The purity and recovery percent was calculated mathematically to be $99.35 \%$ and $63.3 \%$ respectively as shown in Table 1 and the ratio between Ferritin and Total protein concentration during purification steps can be also summarized as shown in Figure 1

\section{The ${ }^{125}$ I- ferritin Tracer}

Purification of ferritin tracer from the radioiodinated reaction mixture takes place on sephadex G-25 column and radiochemical yield and purity was calculated.

\section{Radiochemical yield \%}

The radiochemical yield percent calculated using the following equation:

Radiochemical yield $\%=\frac{\text { Radioactivity of }{ }^{125} \text { I-ferritin tracer peak }}{\text { Total radioactivity of fractions }} \times 100$

The radiochemical yield percent of ${ }^{125} \mathrm{I}$-ferritin tracer was $27.4 \pm 0.21 \%$ Fig. 2 .

\section{Radiochemical purity \%}

The purification profile of ${ }^{125}$ I-ferritn tracer was determined using paper electrophoresis and calculated as following:

Radiochemical purity $\%=\frac{\text { Radioactivity of }{ }^{125} \text { I-ferritin tracer peak }}{\text { Total radioactivity on the paper }} \times 100$

It shows radiochemical purity percent of $97.4 \%$ as illustrated in Fig. 3 with specific activity of $26.5 \pm 0.01 \mu \mathrm{Ci} / \mu \mathrm{g}$.

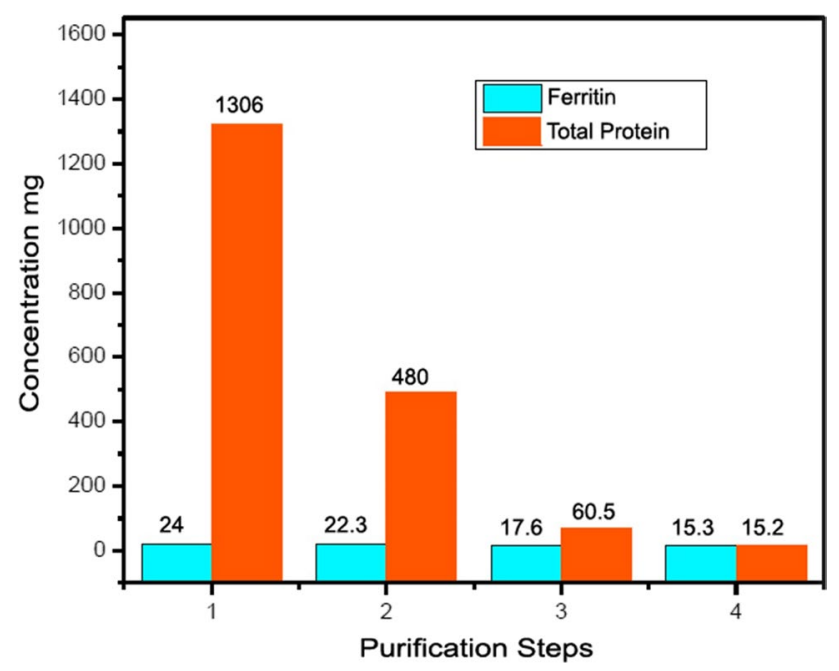

Fig. 1 Ratio between ferritin and total protein during purification steps

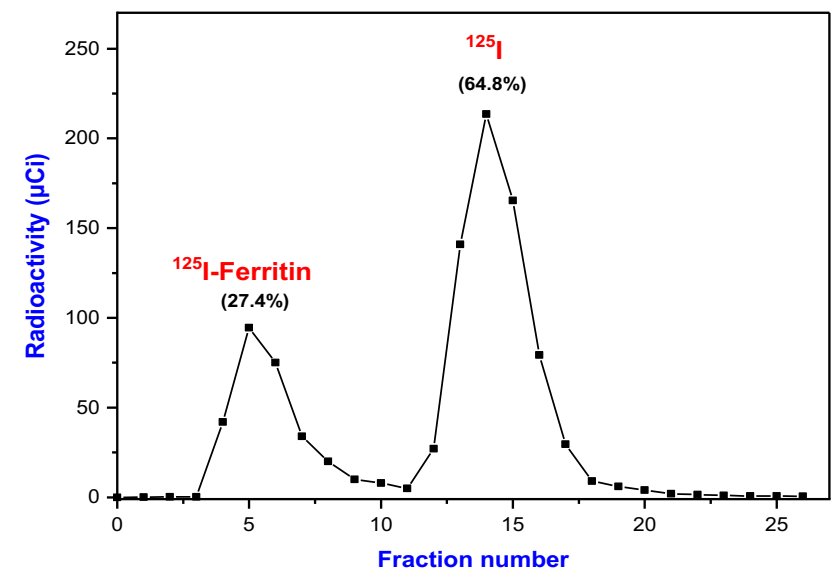

Fig. 2 Purification of ${ }^{125} \mathrm{I}$ - ferritin RIA tracer using sephadex G-25 column (flow rate $0.5 \mathrm{ml} / \mathrm{min}$.)

\section{Optimization of factors affecting the iodination process}

Studying the factors affecting the radiochemical yield of ferritin tracer shows that:

The best radiochemical yield resulted when using $20 \mu \mathrm{g}$ of chloramine-T and $10 \mu \mathrm{g}$ of substrate (ferritin) at $\mathrm{pH} 7.4$ for $30 \mathrm{~s}$ reaction time Fig. 4.

\section{Ferritin polyclonal antibody production}

The data obtained from rabbits used in this study showed that the anti-sera obtained from bleed number five of rabbit no. 1 gave the highest displacement percent 70.2 at dilution 1:10,000 as shown in Fig. 5.

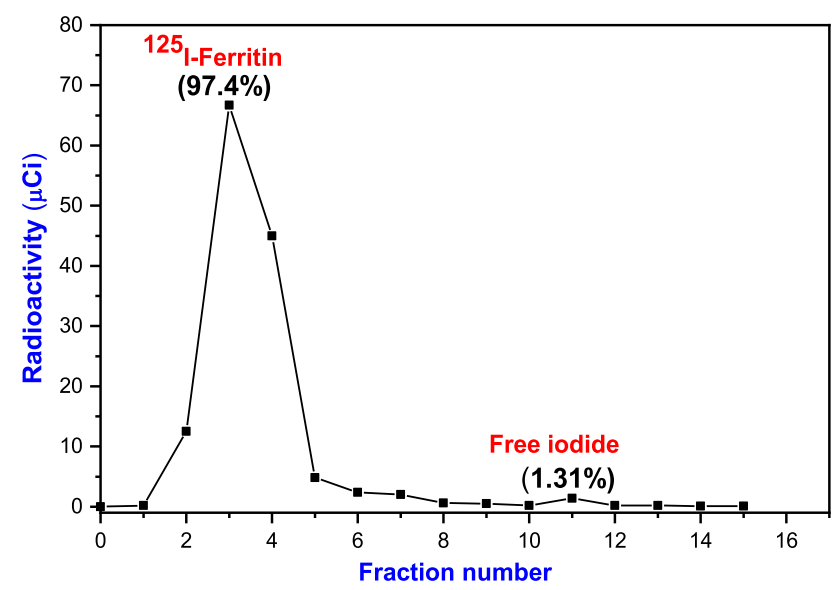

Fig. 3 Electrophoretical pattern of radiochemical purity of produced ${ }^{125}$ I-Ferritin tracer 

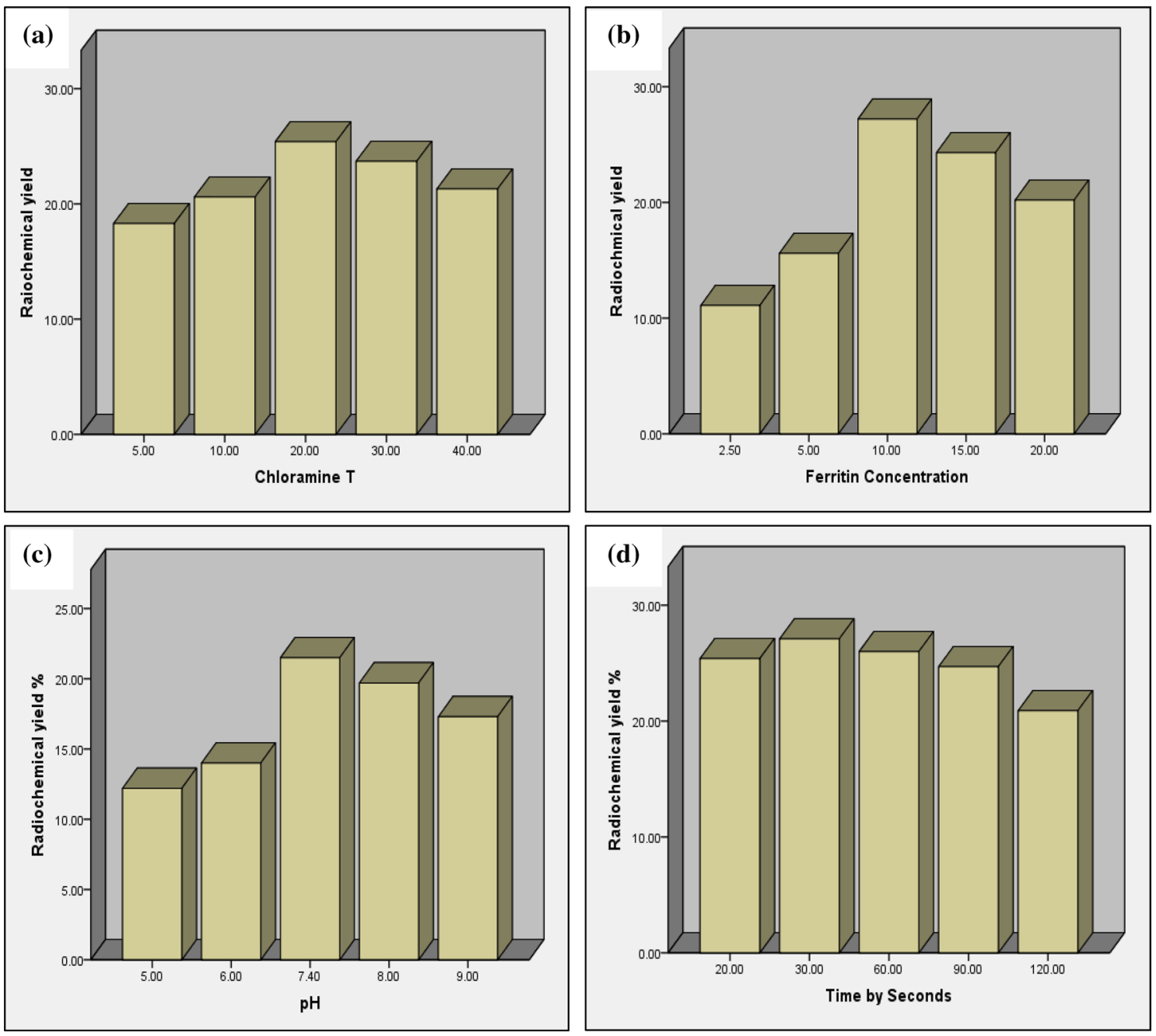

Fig. 4 Factors affecting the radiochemical yield of ferritin tracera) Effect of chloramine-T concentration $\mathbf{b}$ Effect of ferritin concentration $\mathbf{c}$ Effect of $\mathrm{pH} \mathbf{d}$ Effect of reaction time

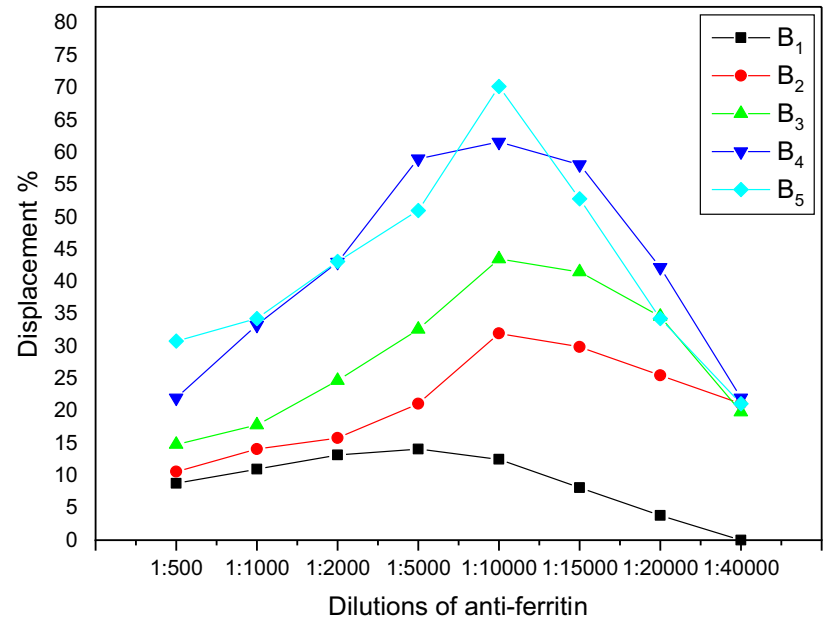

Fig. 5 Displacement of ferritin Polyclonal antibody for rabbit no. 1 during the 5 bleeds
Table 2 Optimum conditions used to construct the standard curve

\begin{tabular}{lll}
\hline Incubation time & Incubation temperature & Sample volume \\
\hline $3 \mathrm{~h}$ & $37{ }^{\circ} \mathrm{C}$ & $100 \mu \mathrm{l}$ \\
PEG 12\% volume & 2nd antibody dilution & Normal rabbit \\
& & serum dilu- \\
& & tion \\
$500 \mu \mathrm{l}$ & $1: 40$ & $1: 200$ \\
\hline
\end{tabular}

\section{Ferritin radioimmunoassay optimum conditions}

Optimum conditions for all parameters needed in radioimmunoassay system were studied to achieve the best results and accurate standard curve. The results can be summarized as following Table 2 


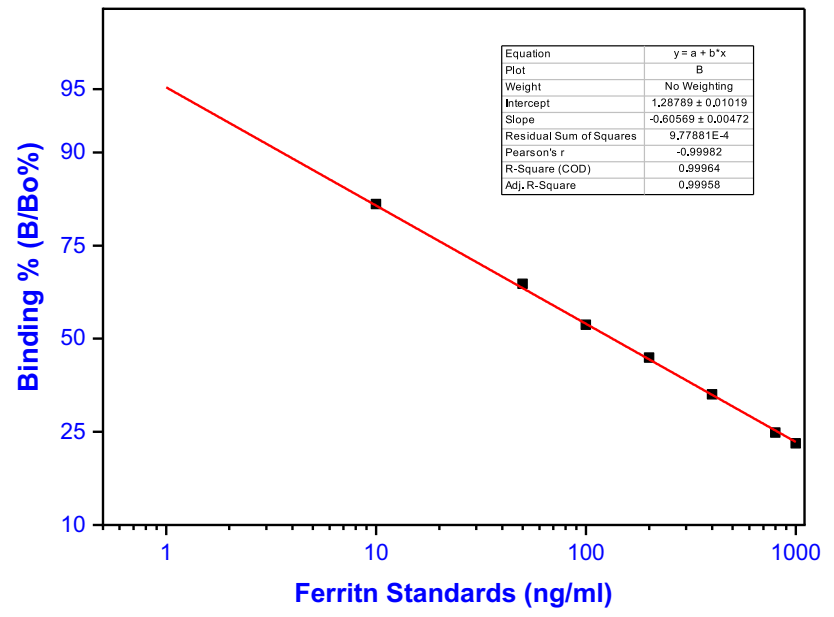

Fig. 6 Optimized standard curve for ferritin using liquid phase RIA system

Table 3 The sensitivity of ferritin liquid phase RIA system

\begin{tabular}{lllll}
\hline $\begin{array}{l}\text { Cpm (Mean- } \\
\text { SD) }\end{array}$ & $\begin{array}{l}\text { Cpm (Mean- } \\
\text { 2SD) }\end{array}$ & B/Bo \% & $\begin{array}{l}\text { Apparent } \\
\text { concentra- } \\
\text { tion (ng/ml) }\end{array}$ & $\begin{array}{l}\text { Approximate } \\
\text { sensitivity (ng/ } \\
\text { ml) }\end{array}$ \\
\hline $12,228-135$ & 11,958 & 94.95 & 1 & 1 \\
\hline
\end{tabular}

\section{The optimized assay design}

The assay was designed using optimum conditions studied as following: $100 \mu \mathrm{l}$ ferritin standards or serum samples and $100 \mu \mathrm{l}$ of locally prepared ${ }^{125} \mathrm{I}$-ferritin tracer were added to $100 \mu \mathrm{l}$ ferritin polyclonal antibody $(1 / 10,000$ dilution of 5 th bleed from rabbit 1) in polystyrene tubes. The contents of the tubes were mixed together and incubated for $3 \mathrm{~h}$ at $37^{\circ} \mathrm{C}$. The separating agent was introduced at the conclusion of the incubation period, commencing with $100 \mu$ l goat anti-rabbit IgG, $100 \mu$ non-immunized rabbit serum, and $500 \mu$ l PEG8000 . Assay tubes were mixed with a vortex and incubated for $30 \mathrm{~min}$ at room temperature before being centrifuged at $4000 \mathrm{rpm}$ for $20 \mathrm{~min}$ at $4{ }^{\circ} \mathrm{C}$. The tubes were carefully decanted and precipitated antigen-antibody complex was counted in a multi-crystal gamma counter, the data were calculated, and the standard curve was drawn as shown in Fig. 6.

\section{Validation of the assay}

To assure the validity and reliability of the suggested assay, some performance characteristics were studied.
Table 4 Intra-assay precision for ferritin using liquid phase RIA system

\begin{tabular}{llll}
\hline Samples & $\begin{array}{l}\text { Intra-assay } \\
\text { Mean }(\mathrm{ng} / \mathrm{ml})\end{array}$ & SD (ng/ml) & CV\% \\
\hline Low & 14.6 & \pm 0.65 & 4.5 \\
Normal & 122.5 & \pm 2.1 & 1.7 \\
High & 346.1 & \pm 6.3 & 1.8 \\
\hline
\end{tabular}

Table 5 Inter-assay precision for ferritin using liquid phase RIA system

\begin{tabular}{llll}
\hline Samples & $\begin{array}{l}\text { Inter-assay } \\
\text { Mean }(\mathrm{ng} / \mathrm{ml})\end{array}$ & SD (ng/ml) & CV\% \\
\hline Low & 15.3 & \pm 0.8 & 5.2 \\
Normal & 124.1 & \pm 4.5 & 3.6 \\
High & 344.2 & \pm 8.9 & 2.6 \\
\hline
\end{tabular}

\section{Sensitivity of the assay}

The results of the present study showed that the minimum detection limit of the assay is approximately $1 \mathrm{ng} / \mathrm{ml}$ which reflects the high sensitivity of this technique in measurement of ferritin in human serum Table 3

\section{Precision}

\section{Intra-assay precision (within run)}

Mean, Standard deviation and coefficient of variation were calculated for 10 replicates of low, medium and high human ferritin samples in a single run. The $\mathrm{CV} \%$ results ranged from 1.7 to $4.5 \%$ Table 4 .

\section{Inter-assay precession (Run to run)}

Mean, Standard deviation and coefficient of variation were calculated for 10 replicates of low, medium and high human ferritin samples in 10 separate runs. The $\mathrm{CV} \%$ results ranged from 2.6 to $5.2 \%$ Table 5 .

The present study's intra-assay and inter-assay data demonstrated that the results produced by the current procedure were consistent. The findings are in accordance with Pillai and Bhandarkar [21] and Ragab et al. [22], who stated that intra-assay CVs should be less than $10 \%$ and inter-assay CVs should be less than $15 \%$.

\section{Accuracy}

\section{Recovery test}

As shown from results listed in Table 6, it can be observed that recovery percentage for ferritin samples $(25.2,185.6$ 
Table 6 Recovery assessment for ferritin using liquid phase RIA system

\begin{tabular}{llrlcc}
\hline Sample & $\begin{array}{l}\text { Endogenous } \\
(\mathrm{ng} / \mathrm{ml})\end{array}$ & Added $(\mathrm{ng} / \mathrm{ml})$ & Expected $(\mathrm{ng} / \mathrm{ml})$ & Observed $(\mathrm{ng} / \mathrm{ml})$ & Recovery $(\%)$ \\
\hline 1 & 25.2 & 20 & 22.60 & 22.22 & 98.3 \\
& & 87.60 & 92.77 & 105.9 \\
& & 150 & 187.60 & 173.72 & 92.6 \\
2 & 350 & 102.80 & 107.22 & 104.3 \\
& \multirow{2}{*}{185.6} & 167.80 & 155.55 & 92.7 \\
& & 267.80 & 256.28 & 95.7 \\
3 & 350 & 216.25 & 207.21 & 95.82 \\
& \multirow{2}{*}{412.5} & 20 & 281.25 & 251.69 & 89.49 \\
& & 381.25 & 410.99 & 107.8 \\
\hline
\end{tabular}

Table 7 Dilution test for ferritin using liquid phase RIA system

\begin{tabular}{|c|c|c|c|c|c|}
\hline Sample & $\begin{array}{l}\text { Endogenous(ng/ } \\
\mathrm{ml})\end{array}$ & Dilutionfactor & Expected(ng/ml) & Observed(ng/ml) & Recovery $(\%)$ \\
\hline \multirow[t]{4}{*}{1} & \multirow[t]{4}{*}{185.6} & $1: 2$ & 92.8 & 90.8 & 97.8 \\
\hline & & $1: 4$ & 46.4 & 47.5 & 102.3 \\
\hline & & $1: 8$ & 23.2 & 22.1 & 95.2 \\
\hline & & $1: 16$ & 11.6 & 11.0 & 94.7 \\
\hline \multirow[t]{4}{*}{2} & \multirow[t]{4}{*}{412.5} & $1: 2$ & 206.3 & 209.3 & 101.5 \\
\hline & & $1: 4$ & 103.1 & 108.6 & 105.3 \\
\hline & & $1: 8$ & 51.6 & 48.3 & 93.6 \\
\hline & & $1: 16$ & 25.8 & 25.0 & 97.1 \\
\hline \multirow[t]{4}{*}{3} & \multirow[t]{4}{*}{649.2} & $1: 2$ & 324.6 & 303.5 & 93.5 \\
\hline & & $1: 4$ & 162.3 & 160.8 & 99.1 \\
\hline & & $1: 8$ & 81.2 & 83.2 & 102.5 \\
\hline & & $1: 16$ & 40.6 & 44.6 & 109.8 \\
\hline
\end{tabular}

and 412.5) ranged from (92.6 to 105.9$),(92.7$ to 104.3$)$ and (89.49 to 107.8 ) respectively. The recovery data of the present study for ferritin indicates accurate calibration and an appropriate matrix.

\section{Dilution test:}

The results in Table 7 reveal the concentrations of three human samples $(185.6,412.5,649.2)$ undiluted and at various dilutions in the assay buffer to assess the linearity of the assay. The recovery percentage was ranged from (94.7 to $102.3 \%)$, (93.6 to $105.3 \%$ ) and (93.5 to $109.8 \%$ ) respectively, this indicates to good linearity under several dilutions.

\section{Method comparison}

The statistical analysis (linear regression and correlation coefficient " $r$ ") were carried out to compare ferritin results for 50 different human serum samples with values ranged from 5 to $650 \mathrm{ng} / \mathrm{ml}$ measured by the prepared system

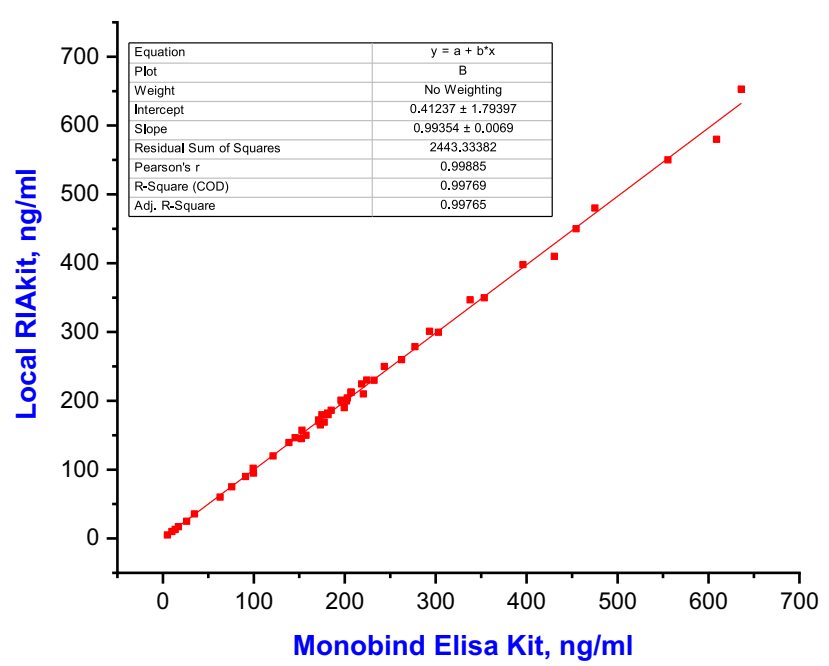

Fig. 7 Regression line equation and correlation coefficient " $r$ " between ferritin values obtained by Monobind Elisa kit and the local liquid phase RIA system 
(ferritin liquid phase RIA) versus results measured using commercially available kits (Monobind Elisa kit).The statistical calculations show good correlations between the results obtained from the prepared system and the commercially available kits $(r=0.998)$ Fig. 7.

\section{Conclusion}

Radioimmunoassay system for ferritin in this report was developed, optimized and validated. The assay exhibited high senstivity of $1 \mathrm{ng} / \mathrm{mL}$, acceptable imprecision level of less than $5.2 \%$, recovery between 89.49 and $107.8 \%$ and linearity of dilution between 93.5 and $109.8 \%$. The developed assay system can be used for routine sample analysis of ferritin in human serum as a laboratory biomarker in Covid-19 patients.

Funding Open access funding provided by The Science, Technology.

Open Access This article is licensed under a Creative Commons Attribution 4.0 International License, which permits use, sharing, adaptation, distribution and reproduction in any medium or format, as long as you give appropriate credit to the original author(s) and the source, provide a link to the Creative Commons licence, and indicate if changes were made. The images or other third party material in this article are included in the article's Creative Commons licence, unless indicated otherwise in a credit line to the material. If material is not included in the article's Creative Commons licence and your intended use is not permitted by statutory regulation or exceeds the permitted use, you will need to obtain permission directly from the copyright holder. To view a copy of this licence, visit http://creativecommons.org/licenses/by/4.0/.

\section{References}

1. WHO (2021) World Health Organization. Coronavirus disease 2019 (COVID- 19) Weekly epidemiological update.

2. Pranata R, Huang I, Lukito AA, Raharjo SB (2020) Elevated $\mathrm{N}$-terminal pro-brain natriuretic peptide is associated with increased mortality in patients with COVID-19: systematic review and meta-analysis. Postgrad Med J 96(1137):387-391

3. Huang I, Lim MA, Pranata R (2020) Diabetes mellitus is associated with increased mortality and severity of disease in COVID19 pneumonia-a systematic review, meta-analysis, and metaregression. Diabet \& Metab Syndr Clin Res \& Rev 14(4):395-403

4. Pranata R, Huang I, Lim MA, Wahjoepramono EJ, July J (2020) Impact of cerebrovascular and cardiovascular diseases on mortality and severity of COVID-19-systematic review, meta-analysis, and meta-regression. J Stroke Cerebrovasc Dis 29(8): 104949

5. Huang I, Pranata R (2020) Lymphopenia in severe coronavirus disease-2019 (COVID-19): systematic review and meta-analysis. J Intensive Care 8(1):1-10

6. Mehta P, McAuley DF, Brown M, Sanchez E, Tattersall RS, Manson JJ, Collaboration HAS (2020) COVID-19: consider cytokine storm syndromes and immunosuppression. Lancet (London, England) 395(10229):1033

7. Pan Y (2006) Why do African Americans have higher serum ferritin than European Americans, despite lower hemoglobin?,

8. Lipschitz DA, Cook JD, Finch CA (1974) A clinical evaluation of serum ferritin as an index of iron stores. N Engl J Med 290(22):1213-1216

9. Kratz A, Ferraro M, Sluss PM, Lewandrowski KB (2004) Laboratory reference values. N Engl J Med 351:1548-1564

10. Skelley DS, Brown LP, Besch PK (1973) Radioimmunoassay. Clin Chem 19(2):146-186. https://doi.org/10.1093/clinchem/19.2.146

11. Mehany N, Sallam KM, El-Bayoumy A (2016) Development of solid phase immunoradiometric assay for determination of carcinoembryonic antigen as a tumor marker. J Radioanal Nucl Chem 307(2):1375-1383

12. Suryakala S, Deshpande V (1999) Purification and characterization of liver ferritins from different animal species. Vet Res Commun 23(3):165-181

13. Cetinkaya N, Lengemann F, Kogan P (1985) Isolation, purification and characterization of bovine spleen ferritin. Comp Biochem Physiol B: Comp Biochem 80(4):773-778

14. Page M, Lagueux J, Gauthier C (1980) A three step purification procedure for human liver ferritin. Can J Biochem 58(6):494-498

15. Hunter WM, Greenwood FC (1962) Preparation of iodine-131 labelled human growth hormone of high specific activity. Nature 194(4827):495-496

16. Barnett M, Gordon Y, Amess J, Mollin D (1978) Measurement of ferritin in serum by radioimmunoassay. J Clin Pathol 31(8):742-748

17. Goldie D, Thomas M (1978) Measurement of serum ferritin by radioimmunoassay. Ann Clin Biochem 15(1-6):102-108

18. Zola H (2013) Monoclonal antibodies: a manual of techniques. CRC Press, Boca Raton

19. Pillai M, Bhandarkar S (1994) Radioimmunoassay: principles and practice. 2.

20. Deppe W, Joubert S, Naidoo P (1978) Radioimmunoassay of serum ferritin. J Clin Pathol 31(9):872-877

21. Pillai M, Bhandarkar S (1998) Radioimmunoassay Princ Pract 3:40-98

22. Ragab M, Moustafa K, El-Kolaly M (2002) Development of Solid phase radioimmunoassay for triiodothothyronine using antibodycoupled magnetizable particles. Arab J Nucl Sci Appl 35(2):63-75

Publisher's Note Springer Nature remains neutral with regard to jurisdictional claims in published maps and institutional affiliations. 